\title{
The voice of dwellers - developing a place brand by listening to its residents
}

\author{
Ulla Hakala \\ Department of Marketing and International Business, University of Turku, \\ Turku, Finland
}

\begin{abstract}
Purpose - Listening to the customers has long been a key phrase and success element in product branding. This paper aims to highlight the importance of listening to residents during the branding of a place. The study explores ways of listening to residents to ensure they are heard and also discusses the challenges and benefits related to place branding flowing from having residents participate in decision-making processes.

Design/methodology/approach - Listening to residents and offering opportunities to participate requires place branders to fully attend to, comprehend and respond to residents' comments, requests, ideas and feedback. This study reports on how two Nordic cities - Turku and Helsinki - listen to their residents. The data used comprise face-to-face interviews, telephone and e-mail conversations and documentary material.

Findings - Residents should not be considered as one homogeneous target; participation options and channels should be adapted to the demographics and geographic issues of the different regions and resident groups.

Research limitations/implications - The role of residents and the importance of listening are crucial features in the emerging concept of inclusive place branding (Kavaratzis et al., 2017); its future conceptual development could benefit from the case examples at hand.

Practical implications - City authorities should listen to residents and provide them with opportunities to actively contribute to decision-making. Other cities could learn from the examples introduced in the paper.

Originality/value - This paper documents two Nordic examples of cities putting into practice a policy of listening to the residents, a previously neglected research area.
\end{abstract}

Keywords Stakeholders, Participation, Residents, Listening, City governance, Inclusive place branding

Paper type Research paper

\section{Introduction}

"Citizenship is not an a priori given but is constructed in interaction in the context of participation.” (Adapted from Turnhout et al., 2010)

Listening to the customers has long been the key phrase and success element in product branding (Ramsey and Sohi, 1997). In this paper, the importance of listening to existing residents is

(C) Ulla Hakala. Published by Emerald Publishing Limited. This article is published under the Creative Commons Attribution (CC BY 4.0) licence. Anyone may reproduce, distribute, translate and create derivative works of this article (for both commercial and non-commercial purposes), subject to full attribution to the original publication and authors. The full terms of this licence may be seen at http:// creativecommons.org/licences/by/4.0/legalcode

The author wants to thank the three anonymous reviewers for their invaluable feedback and help in revising and developing the paper. Special thanks also to the Foundation for Economic Education, Finland, for the financial support of the study.
Voice of dwellers

Received 15 December 2019 Revised 30 March 2020 12 September 2020 24 December 2020

20 January 2021 Accepted 26 January 2021

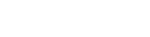


JPMD

14,3

highlighted in the development of branding a place. In place marketing and branding, listening can be positioned within the approach of inclusive place branding - an emerging concept that emphasizes the importance of listening - is inspired by an ideology of justice and inclusion, is situated in local contexts and focuses on the residents (Lichrou et al., 2017). Today's market-based public management addresses citizens [1] more like customers (Eshuis et al., 2013). The number and heterogeneity of the residents and also the fact of their being scattered around different areas and locations makes it challenging to hear them. The participation of and dialogue with all stakeholders, including residents, is extremely important in branding a place (Lucarelli and Giovanardi, 2016; Zenker and Erfgen, 2014; Freire, 2009). In line with this, Eshuis et al. (2014; see also Eshuis and Edwards, 2013) show how citizen involvement can be used to enhance the quality of a place brand but its potential is not fully realized in practice and theory. Indeed, research is lagging in terms of the attention paid to listening and participatory perspectives on place branding, and hence, there is a need for more research on the topic to help build a culture of listening in cities (Macnamara, 2016). Furthermore, Compte-Pujol et al. (2019; see also Merrilees et al., 2009; Kalandides, 2011) have illustrated the need for a closer examination of the role of residents in place branding to determine what cities are really doing in terms of advancing participatory processes. Freire (2009) states that when research is about place branding, decisions should be made concerning target audiences, who are referred to here as residents.

Having said that, the purpose of this paper is to explore ways of listening to the residents, that is, ways to make them heard. For this purpose, the following research questions are proposed:

RQ1. How do the cities of Helsinki and Turku in Finland listen to their residents?

$R Q 2$. How can cities override the challenges that are involved with listening?

RQ3. How can they make sure that participation is not exclusive, selective or restricted to just those who are active?

To answer the first question, the two Nordic cities are used to exemplify how listening can happen in practice. The answer to the second research question is based on the theoretical discussion on the challenges that listening may cause and how Helsinki and Turku have overridden them. The theoretical background of the study is built on participatory place branding and city governance, as well as organizational listening. The underlying assumption is that interactive, two-way processes increase emotional involvement, commitment and attachment to a place, thereby establishing loyalty. According to previous literature (see e.g. Insch and Florek, 2010), the development of emotional bonds is a prerequisite of involvement in local activities. Creating a strong emotional bond with the brand of a person's place is also the purpose, as of any branding (Eshuis et al., 2013).

Focusing on the concept of listening and its importance, this paper reports on two examples where residents have been given a voice. Traditionally, Finnish city governance has been based on political policy-making and local self-government safeguarded by the country's constitution. Municipal elections every four years offer citizens a say in who represents them on the municipal council, the supreme decision-making body. In recent years, because of the renewal of the Local Government Act (2015), cities have increasingly tried to include their citizens in planning processes at an early stage as the political nature of place management calls for democratic legitimacy (Kuntaliitto, 2020; Lichrou et al., 2017; Eshuis and Edwards, 2013).

The first case example relates to a program known as the Mayor's Visits in the city of Turku and the second to the involvement in participatory budgeting of the residents of the City of Helsinki. Although researchers and practitioners agree on the need to listen to the residents, little is written about how they can become involved and participate in municipal affairs and what the intended and unintended consequences are. The two cases are 
interesting in the sense that they show how resident participation has been put into practice, and hence, offer best practice examples other cities could learn from. In addition to its managerial implications, this study contributes to the scientific debate about listening and resident participation by diligently documenting both cases.

The remainder of the paper proceeds as follows. Next, the theoretical framework is presented by discussing place branding and urban governance, listening and resident participation. After outlining the methodology and documenting the various forms of data collection, the findings are presented. Despite the benefits of residents' participation and involvement, some inherent challenges can jeopardize the objectives of that inclusion policy. Those challenges are reviewed in the discussion section. The paper concludes by discussing the theoretical contribution and managerial implications and its limitations and directions for future research.

\section{Place branding and urban governance}

Commercial producers have long seen the advantage of branding their products but during the past three decades, brand-management philosophy has extended to include public and spatial contexts, that is, place branding and marketing-led strategies have come to play a more important role in place development (Eshuis and Edwards, 2013). The need for towns, cities and communities to differentiate themselves from competitors has become critical for them to attract people to live, work and feel at home in the place (Hudson et al., 2017). According to Braun et al. (2013; see also Zenker and Braun, 2017; Morgan et al., 2003; Kavaratzis, 2009; Baker, 2012), branding a place is a strategic process that requires the continuing advocacy and committed support of local individuals and organizations, that is, letting the place brand grow from the bottom. Moreover, the more committed people are to the place and its brand, to begin with, the more likely they are to participate in its development (cf., Xiong and King, 2015). A strategy that incorporates the wider community is more likely to gain approval and be sustainable over time. Place branding has been criticized for creating a gap between image and reality (Eshuis and Edwards, 2013) if those who live in the place are not consulted.

Advocating greater citizen engagement, Blomgren Bingham et al. (2005) underline the importance of horizontal structures of governance as opposed to hierarchical organizational decision-making in public administration. There have also been calls for improvement to the collaboration, negotiation and facilitation skills of public managers. According to Eshuis et al. (2013; also, Eshuis et al., 2014), place marketing and branding have evolved to become an integral part of urban governance for managing perceptions about places. The perceptions are affected by the ability of the stakeholders to contribute ideas on economic and spatial development (Eshuis and Edwards, 2013). Indeed, urban governance highlights the importance of resident participation in governance processes, providing not only tools but also practices and processes for people to participate and work for the common good via civic engagement. As for city management, urban governance entails an emphasis on activation, enablement, negotiation, collaboration, orchestration and also for modulation skills, that is, activating and enabling people to participate, collaborate and negotiate with them and orchestrating the procedure. Modulation means providing incentives to elicit cooperative behavior. Participatory budgeting, which will be discussed in the empirical section of the study, is often mentioned as a form of urban governance (Blomgren Bingham et al., 2005).

Developing a participatory process between residents and their local government is essential for building a strong place brand (Lichrou et al., 2017; Insch and Stuart, 2015). However, complexities arise from the number of stakeholders (Cassinger and Eksell, 2017; 
JPMD

14,3

\section{0}

Roper and Davies, 2007; Kavaratzis and Ashworth, 2005), if there are many separate but interrelated districts (Zenker and Petersen, 2014), the number of organizations steering the brand (Hakala et al., 2020), as well as the limited control of the brand and the diverse target groups (Zenker and Braun, 2017; Virgo and de Chernatony, 2006). Cities' powers to enact policy are limited by judicial regulations and political decisions and they cannot exercise the economic power of private corporations (Frug, 1984; Lucarelli and Giovanardi, 2016). Furthermore, places do not have single identities that can be clearly branded; they can have different attractions and different meanings to diverse target markets (Zenker and Braun, 2017; Eshuis et al., 2013; Skinner, 2008). Indeed, a growing number of researchers understand the place brand as a set or network of associations in the minds of the place's stakeholders (Zenker and Erfgen, 2014; Zenker and Braun, 2010a, 2010b).

Place branding is a matter of compromise, shared values and collective benefits and it is important to understand who the key stakeholders to be involved in the brand's construction are and in what potential capacity (cf. Freire, 2009). If local people are to identify favorably with a place and to become brand ambassadors rather than critics, successful implementation requires long-term advocacy and support of local individuals and organizations (Morgan et al., 2003; Baker, 2012; Zenker and Petersen, 2014). However, place branding can never start from scratch; each place has its own history, heritage and infrastructure and consequently, the creation and communication of the place brand are often beyond the control of the marketer (Braun et al., 2014; Trueman et al., 2007).

Zenker and Erfgen (2014) have suggested a three-stage participatory place branding strategy that starts from capturing the key components of the place and defining a shared vision for the place. Accordingly, Olsson and Berglund (2009) underline the need to analyze the interests, attitudes and demands of various target groups. Second, a structure for participation should be implemented and guidelines for participation developed. Third, support should be provided to the residents in implementing their projects and finally, the success of the project should be assessed.

According to a former deputy mayor of Helsinki, Pekka Sauri, reliability and creativity are the key features of the success of a city (Sauri, 2017). Reliability means everybody obeying the same rules and principles and everybody being treated the same way. By creativity, Sauri (2017) means that the residents' innovativeness and initiative are supported, not limited or restricted by unnecessary regulations. These features refer to participatory city branding (see e.g. Zenker and Erfgen, 2014; Braun et al., 2013; Colomb and Kalandides, 2010). The participatory approach highlights the significance of internal audiences, by trying to increase brand commitment (Ind and Bjerke, 2007; Hatch and Schultz, 2009). The participation in question can concern both city development and residents' contribution to the promotional imagery; however, excluding the people from wider urban developments and having them influence only symbolic representation is questioned by Eshuis and Edwards (2013), among others.

Zakarevičius and Lionikaite (2013) assert that internal stakeholders, particularly the residents, do not only place consumers but an important group of brand formers and a significant group of place developers (Hakala et al., 2020). Their role is, however, indirect as the case examples here illustrate; residents seldom take part in the actual implementation of place branding strategies (Compte-Pujol et al., 2019), but they can have a significant impact on the place brand via their behavior, initiatives, WOM and eWOM communication and their encounters with tourists and other external stakeholders. Consequently, and as underlined by Insch and Stuart (2015), developing a participatory process between residents and local government is essential for building strong place brands. 
Braun et al. (2013) present three roles of residents that make them important actors in place branding activity:

- Residents as an integrated part of place branding: residents and their interactions with each other and with outsiders build the place's social ambiance, making them the "bread and butter" of a place. In his article, Freire (2009) argued that local people have such a relevant impact on a place brand that they may even affect its competitive position in the market. In the competition for residents (Zenker et al., 2013), cities try to build a favorable image among their residents to transform them into ambassadors for the city.

- Residents as ambassadors for their place brand: The views of residents are significant in building the city image as residents are considered authentic, insider sources of information. The word-of-mouth disseminated by the residents is evidenced to be more trustworthy than a paid promotion (Colicev et al., 2018; Olsson and Berglund, 2009). Moreover, Zenker and Erfgen (2014) refer to residents as ambassadors who constitute the most valuable assets for place branding.

- Residents as citizens and voters. According to this view, place authorities are obliged to guarantee that the residents can participate in choosing/voting for their local city representatives, and thus they have political power, but place authorities should also provide citizens opportunities to actively contribute to decision-making (Zenker and Braun, 2017; Eshuis and Edwards, 2013; Keller, 1993). Doing so can, however, be challenging as branding needs a core focus to differentiate the offering from that of competitors (Keller, 1993).

An emerging approach emphasizing the role of residents, albeit one as yet lacking an established definition, was introduced by Kavaratzis et al. (2017) in a book on inclusive place branding that offers an initial definition of the concept as "a form of place branding that:

- goes beyond economic interests and goals;

- focuses on the residents;

- integrates the voices of many stakeholders through participatory methods; and

- 'listens' to the non-powerful” (Lichrou et al., 2017, p. 27).

The two case examples in the study at hand follow those features and could, thus, be used to aid the future development of the concept.

\section{Voice and listening}

Many authors have recently noted the importance of listening and its fundamental role in dialogue and communication: without a listener, speech is only noise in the air (Lichrou et al., 2017; Macnamara, 2016; Lacey, 2013). Having a voice is used as a metaphor for representation and human rights in a democracy, which is based on vox populi - the wisdom of crowds (Surowiecki, 2004). Surowiecki (ibid.) asserts that groups are often wiser than the wisest people in them and they can excel if there is: diversity of opinion within the group, independence of judgment, decentralization drawing on local knowledge and aggregation, that is, a mechanism that turns the individual judgments into a collective decision. Similarly, Steil et al. (1983) have suggested that there are three essential components to listening: sensing, evaluating and responding. Adapting the three components to the context of public administration and urban governance, it is possible to conclude that it is important for cities to sense the stimuli originating with their citizens, 
JPMD

14,3

282

evaluate their importance and respond to the initiatives undertaken by the people; in short, to be attentive.

These components align with effective ethical listening that Macnamara (2016) operationalized as recognition, acknowledgment, paying attention, constructing meaning, achieving understanding, giving consideration and finally, responding. Listening is, thus, the focal consequence of speaking and a requirement to achieve two-way communication, dialogue and active relationships. According to Ramsey and Sohi (1997; see also Lacey, 2013), effective listening is not merely hearing what the other party is saying but getting the meaning of what is being said. Listening helps city managers gather information and to understand their stakeholders' needs.

Macnamara (2016) lists the prerequisites of effective organizational listening: First, an open culture for listening; second, open and interactive systems and platforms facilitating people having their say; third, technologies that facilitate listening; and fourth, resources including staff assigned to operate listening systems and to offer assistance when needed. However, despite its importance and proven benefits (see e.g. Yang et al., 2015; Lacey, 2013), listening is little studied or discussed on the organization - public level and this study aim to address that gap. Listening is a prerequisite of participation, another central theme in this study and is discussed next.

\section{Participation - a corollary of listening}

Listening to the residents and including them in the decision-making relating to a place are often neglected even though political and social democratic rights of citizenship emphasize a participatory paradigm (García, 2006). As far back as the late 1960s, Arnstein (1969) highlighted the importance of citizen participation, describing it as the cornerstone of democracy. Participation involves listening and trust. Active participation cannot flourish without listening and dialogue and city officials may end up breaching the implied trust of the citizens (cf., Schultz and McGinn, 2012).

The relationship between residents and their living environment has been a significant topic in environmental psychology (Rioux and Werner, 2011), in educational studies (Schultz and McGinn, 2012) and in urban planning (Olsson and Berglund, 2009) but in the marketing and place branding arenas, research on residents' participation on a strategic level and its contribution to city management is limited (Zenker and Erfgen, 2014; Zenker and Seigis, 2012; Braun et al., 2013; Olsson and Berglund, 2009; Merrilees et al., 2009). Consequently, the topic merits further attention. Letting those involved participate in planning and decisionmaking processes is claimed to have considerable benefits (Zenker and Seigis, 2012).

Those benefits can, however, differ as participation can take many different forms, both the range of involvement and the extent of the citizens' power can vary and conceptually public participation is "something rather vague" (Olsson and Berglund, 2009, 132; see also Arnstein, 1969; Alexander, 2008) In 1969, Arnstein developed a model to help understand the intensity of residents' participation that is called the ladder of citizen participation. Contemplating the bare ritual of participation and having the real power to affect the outcome, Arnstein (1969) distinguishes eight different types of participation, the lowest rungs (named manipulation and therapy) do not involve any real citizen participation and include activities by the city authorities to gather information and garner support from the residents. The middle rungs (informing, consultation and placation) consist of token ways of listening, where there is no guarantee that the residents' views and opinions will be taken into account in subsequent decisions. The upper three rungs (partnership, delegated power and citizen control) imbue residents with a greater degree of power and influence in decisionmaking. At the top, participation can mean residents having managerial responsibility for a 
specific program. This, however, is rare as city authorities are usually reluctant to delegate such duties (Insch and Stuart, 2015).

The importance of residents' identification with a place and thereby their willingness to participate have been suggested in person-environment (P-E) and resident-city fit models (Phillips et al., 2010; Fleury-Bahi et al., 2008; Stedman, 2002; Zenker and Petersen, 2014). Based on the empirical results of those studies, a high P-E fit increases social and psychological well-being among residents and also their willingness to engage in placeprotective behavior. Engagement requires empowerment which, besides identification, is achieved through participation (Macnamara, 2016). According to Zenker and Petersen (2014), a high level of identification allows the residents to feel at home in both a physical and emotional sense and to forge a strong bond with their living place, eventually leading to greater acceptance of and commitment to the city and its brand (Insch and Stuart, 2015). However, the participatory processes should be as open and transparent as possible and accessible to all; the ideas should stem from the grassroots level.

In the current digital age, the Belgian city of Hasselt offers a typical example of local people's P-E relationship. The city gathered input from its residents for an urban renewal project. Using a digital platform, the citizens shared how they imagined a large new city park called Kapermolen would look in the future. Van Ransbeeck (2019) talks about smart governance and civic crowdsourcing (or citizen sourcing) and how it is changing the relationship between cities and their citizens. In the traditional governance system, every citizen has a single vote to cast every few years. Today, digital technology makes it easier for citizens to voice their opinions. Hence, governance is not just about obtaining most of the votes during elections but increasingly, it is about efficiently collecting and curating information, coming from citizens and other data points, to enrich the decision-making processes (ibid.).

Residents are invited to participate, either off-line or online, as they are regarded as important representatives of living a place (Rioux and Werner, 2011) and as active coproducers of goods, services and policies (Freire, 2009; Olsson and Berglund, 2009), not merely as passive beneficiaries or place customers. Participation and resident involvement are supposed to have the potential to strengthen public support. Indeed, participation and involvement [2] seem to go hand in hand: according to Zenker and Seigis (2012); involvement on the part of residents seems essential for the successful development of the city and could lead to a greater degree of commitment than is currently the case in most cities. However, Zenker and Erfgen (2014) point out that the form of participation has to be true or real and that involves going beyond just capturing residents' associations through the likes of focusgroup discussions. If trust is placed in residents' initiatives and if the living environment meets the demands of the residents and is accessible and usable by them, they will take responsibility for it and contribute actively to its protection and management (cf. Turnhout et al., 2010; Zenker and Erfgen, 2014). This finding supports the call to transform as many residents as possible into brand champions (cf. Rosenbaum-Elliott et al., 2015). An atmosphere characterized by listening and trust, where stakeholders regularly have the opportunity to participate, is likely to assist in this (Schultz and McGinn, 2012).

But how to make sure the residents' voice is heard? How can they be engaged in city development and influence the city brand? An interesting example is the "Be Berlin" campaign launched in 2008 which gave Berliners, previously excluded from influencing the city's marketing imagery, an opportunity to shape the external representations of the city by providing personal stories that connected them to the city (Colomb and Kalandides, 2010). One of the characteristics of the content of the campaign was that it included new urban spaces that had previously not been featured in the branding imagery. The Berlin case 
JPMD

14,3

284

focused on the promotional aspect of the city. More recently, Kalandides (2011) analyzed the inherent difficulties and tensions of citizen participation in Bogotá, South America. Similarly, Eshuis and Edwards (2013) investigated the relationship and tensions between branding and democratic urban governance in two Dutch cities. Rebranding a city via cocreation with its residents in Pori, Finland also offers an interesting example of inclusive place branding (Hakala et al., 2020).

Other recent examples closely connected with residents' involvement in city development come from the Nordic cities of Helsinki and Turku in Finland and form the empirical core of this article. Both cities have attempted to improve their service provision and brand by listening to the residents and considering their voice when making decisions, but the two cities adopted different approaches to address the goal. The information for the case examples was elicited by interviewing the representatives of the case organizations and also from documentary material.

\section{Methodology}

The overarching purpose of this study is to explore ways of listening to the residents that ensure their voices are heard and to discuss the challenges and benefits of having residents participate in the decision-making processes for place branding. Empirically the subject was investigated through case research that facilitates the exploration and description of a phenomenon within its real-life context using a variety of data sources (Myers, 2020; Eisenhardt, 1989; Yin, 2003). Flyvbjerg (2006) asserts that case studies are particularly well suited to producing in-depth knowledge about complex phenomena. The comprehensiveness that is a byproduct of the case approach is relevant to this research because of the special nature of the cases in which the residents' participation is highly appreciated by the city administration. Furthermore, the methodology applied facilitates acquiring context-dependent knowledge on two different ways of listening to residents and deepens the theoretical understanding of the phenomenon (Flyvbjerg, 2006). Various forms of data were gathered to capture the versatility of the phenomenon (Table 1).

The primary research method deployed was face-to-face interviews, conducted by the author in Finnish and, following transcription, translated into English. The choice of interviewees was based on purposive sampling (Etikan et al., 2016), that is, interviewing

\begin{tabular}{|c|c|c|}
\hline Type & Case Turku & Case Helsinki \\
\hline Face-to-face interviews & $\begin{array}{l}\text { Area Coordinator, October 30, 2018, 90', } \\
\text { Mayor, October 11, 2019, 44' }\end{array}$ & $\begin{array}{l}\text { Development Manager, } \\
\text { October } 10,2019,55\end{array}$ \\
\hline Telephone discussions & $\begin{array}{l}\text { Area Coordinator, March 5, 2020, 25, } \\
\text { Area Coordinator, November 11, 2020, } 36\end{array}$ & $\begin{array}{l}\text { Development Manager, June } \\
20,2019,45^{\prime}\end{array}$ \\
\hline E-mail correspondence & $\begin{array}{l}\text { Messaging (6) with the Area Coordinator } \\
\text { between June 24, 2019-November 16, } 2020\end{array}$ & $\begin{array}{l}\text { Development Manager, June } \\
24,2019\end{array}$ \\
\hline $\begin{array}{l}\text { City's own material } \\
\text { (PowerPoint presentations; }\end{array}$ & www.turku.fi/kjkylassa & $\begin{array}{l}\text { Sarpo Antti, May 20, } 2019 \\
\text { (PowerPoint) }\end{array}$ \\
\hline Web pages) & $\begin{array}{l}\text { www.turku.fi/ osallistuvabudjetointi } \\
\text { [Resident Budget] }\end{array}$ & $\begin{array}{l}\text { https://OmaStadi.hel.fi/pages/ } \\
\text { voting results } \\
\text { https://OmaStadi.hel.fi/ }\end{array}$ \\
\hline Press articles & $\begin{array}{l}\text { Articles (13) between March } 28,2018- \\
\text { August } 9,2019 \text { in the following } \\
\text { newspapers: Aamuset, Turun Tienoo, } \\
\text { ePressi.com., Turkulainen, Turun } \\
\text { Seutusanomat, Turun Sanomat }\end{array}$ & $\begin{array}{l}\text { Articles (6) in the Helsingin } \\
\text { Sanomat, between May 27, } \\
\text { 2019-August 23, } 2020\end{array}$ \\
\hline
\end{tabular}

Table 1.

Empirical data 
people who were the most well-informed about the cases in question. For the OmaStadi case, the Development Manager (hereafter Interviewee 2), who is responsible for the participatory budget project in Helsinki, was interviewed in October 2019. In Turku, the Mayor (hereafter Interviewee 1), who conceived the idea of the Mayor's Visits (\#kjkylässä), was interviewed similarly in October 2019. The Mayor's Visits call for a great deal of organizing and networking, and hence, it was important to interview the Area Coordinator (hereafter Interviewee 3), who is responsible for citizen participation in Turku and who also provided much of the documentary material informing the project. She was interviewed in October 2018. The interviewees were approached by e-mail (the Mayor and Area Coordinator in Turku) and LinkedIn (the Development Manager of Helsinki).

In addition to the face-to-face interviews, supplementary data were collected via telephone discussions (Interviewee 2, 2019), press articles (comprising all articles on the Mayor's Visits and OmaStadi projects that were published during the research period), e-mails and the cities' own material (PowerPoint presentations, internet pages). The empirical data, in the form of transcripts and documentary material, were compiled into a coherent case study; the whole data collection exercise took place 2018-2020.

The research ethics of the study were assured by first, informing the interviewees about the research and the purpose of the data collection. Second, data protection provisions were carefully adhered to. The interviewees were asked for their permission to have their position and background organization published in the article and their name in the references (Daymon and Holloway, 2011). In addition, the research material has been carefully preserved and will not be accessible to anyone other than the researcher.

As the research was exploratory, an interview protocol was developed for the face-to-face interviews, including a set of pre-determined open-ended questions. After the interviews, the recordings were transcribed in full. The transcriptions were analyzed inductively in line with qualitative textual analysis procedures to identify key issues, themes and concepts discussed by the interviewees. As the number of cases was limited to two (Turku and Helsinki) and the transcribed material comprising just 22 pages of verbatim material, the use of computer-assisted data-analysis software was not considered necessary. The quality of the research was determined according to universally applicable criteria for qualitative research: confirmability, dependability, credibility and transferability. According to Leininger (1994), without the use of explicit criteria, the findings are subject to doubt, questioning and non-confirmability.

For a qualitative study to be confirmable, the researcher must show how the data are linked to their sources and that the findings and conclusions are not based on the researcher's prior assumptions and preconceptions (Daymon and Holloway, 2011; Leininger, 1994). In addition, for the findings to be dependable, they must be consistent and accurate. Daymon and Holloway (2011) suggest a way of achieving dependability is to record the data, methods and decisions made during the research process. A study is credible when the evidence is free from error and distortion, the participants' views and ideas have been reported truthfully and the findings are carefully documented (Daymon and Holloway, 2011; Myers, 2020). To determine credibility, the researcher can use member checking, that is, clarify tentative findings with the participants (Lincoln and Guba, 1985; Koelsch, 2013). The fourth criterion indicating a good standard of qualitative research is transferability, which is analogous to external validity in quantitative research.

To ensure the confirmability of the interview analysis, the informants were asked to review the draft cases and their quoted interview excerpts (Koelsch, 2013). Because of careful transcription and documentation of the data, there were no discrepancy issues. Dependability and credibility were assured through a detailed description of the research 
JPMD

14,3

286

process and careful documentation of the research findings. As to transferability, the case examples were chosen based on their shared similarity with regard to the role of listening. However, acknowledging that even though no two social contexts are ever identical, similarities to another similar situation can contribute to extending knowledge (also Flyvbjerg, 2006).

Cho and Trent (2003) added two forms of validity for qualitative research: transactional and transformational validity. The former refers to aiming to acquire a comprehensive understanding of the interviewees' perception of reality. Transformational validity, in contrast, refers to the usefulness of the analysis and the interpretation of the participants in the sense that they are mobilized to act. Accordingly, to adapt Koelsch (2013), transformationally valid research aims to change rather than mirror the truth. Keeping both forms in mind, this study aims to create a coherent understanding of the possible means of listening in cities and also aims to potentially make an impact on the means other cities adopt to harvest the views of their residents.

As stated above, documentary material was used to supplement information collected through the interviews (Myers, 2020). According to Appleton and Cowley (1997), documentary evidence can provide the researcher with rich information unbiased by the data collection and enable cross-checking of the findings with other sources. The current study uses only documents produced concerning the cases in question by reliable sources, thereby confirming the credibility of the document analysis (Daymon and Holloway, 2011). One of the concerns around using documentary material is construct validity, that is, the extent to which the results of applying documents reflect the underlying theoretical concepts. Accordingly, the researcher established that the documents consulted were prepared beforehand and not produced for the benefit of the study (Ahmed, 2010).

In the following paragraphs, the findings of the two cases are discussed based on the interviews and the documentary material. This section answers the first research question: 1. How do the cities of Helsinki and Turku in Finland listen to their residents?

\section{Two nordic examples of ways of listening to the residents \\ Case example 1: the mayor's visits}

The idea of this study originates from a concept which one person, Minna Arve, initiated when she started her term as Mayor of Turku, Finland, at the beginning of 2018. She was interested in knowing the residents' needs and desires because as she put it, "Collaboration between the residents and city officials should be improved. And to do that, we should listen to what residents consider important in their own living environment" (Interviewee 1, 2019; Turun Sanomat, 2019). Hence, by launching the concept of \#kjkylässä (the Mayor's Visits), she declared her intention to visit different suburbs to hear the residents' thoughts and concerns and to get to know them better (ePressi, 2018).

Rather than actual participation in the decision-making, the mayor calls the visits "a model of genuine, ongoing dialogue where the residents are the initiators of the discourse. [...] The residents prepare the agenda and we sit in" (Interviewee 1, 2019). Turku is the sixth-largest city in the country, with a population of 185000 people. The city is divided into eight regions and the idea of the Mayor's Visits is to have the mayor meet the residents of these regions between two and four times a year. The role of the area coordinator (also interviewed for this study, referred to as Interviewee 3) in organizing the visits is highly important: she is in contact with the residents of the particular region and the city officials responsible for particular fields of operation. "It's important that someone takes up the reins 
and that not everybody answers the questions individually. The communications have to stay consistent." (Interviewee 1, 2019)

The initiative for the visits usually stems from the residents and the area coordinator will then help the residents organize the event. By doing this, the city can also approach segments of the citizenry that would not necessarily be heard in decision-making. Successful events have been organized among teenagers (preserving a local youth club; Kehe, 2018), immigrants (integrating them into society through joint events) and elderly people (in the form of visits to care homes). In addition to the mayor, every event and visit is attended by other representatives of the city administration. The representatives also meet before the events to improve collaboration and prevent silos in the city organization. What is striking, according to Interviewee 1 (2019), is the residents' pride in their area. Before the discussion on the requests and claims, the visits often start with the participants' comments on how "[... . w wonderful this place is to live in" (Turun Sanomat, 2019). It follows that people who are attached to their area are more inclined to participate in the visits and publicly state their needs and desires.

The Mayor's Visits had been happening for two and a half years at the point of data collection and the data indicate support for continuing the practice. The opportunity to meet the mayor and other city representatives face-to-face lowers the barrier around the authorities, engages passive resident segments, enhances collaboration between city officials and prevents silos (Interviewee 3, 2018). Although there are many legislative norms and judicial regulations in the city administration, the mayor emphasizes the authentic opportunities for participation in the process:

"In order to be authentic, the dialogue should be something other than standardized and not previously predefined." (Interviewee 1, 2019)

The Mayor's Visits encourage dialogue by letting the residents propose initiatives concerning their own environment and interests. Thereafter, the area coordinator will compile the suggestions and make sure that the topics are discussed during the scheduled mayor's visit to the area concerned. The program and content of every visit are, thus, tailored: the visits are unique every time, as are Turku residents and residential areas (Turun Sanomat, 2019; ePressi, 2018). The exceptional circumstances caused by the Covid-19 pandemic were also taken into account: the visits were organized virtually as Teams meetings. Before the meetings, residents were provided free training on the use of the meeting application (Area Coordinator, e-mail correspondence November 16, 2020).

As part of the listening concept, various resident subgroups can use their voice in segmented bodies that provide a route to influence decision-making in the city. In Turku, there is a Youth Parliament, Children's Parliament, Immigrant Parliament, Disabled Parliament and Senior Parliament. "We have these influencer forums where residents can nominate their own representatives." This kind of influencing is, however, indirect and filtered in that it is not individual-based (Smith and Zook, 2020). An example of deeper collaboration between the residents and the city is Turku Future Forum where new development projects are discussed in workshops [3]:

[...] "[...] and actually, not only discussed but also put into practice. [...] This kind of collaboration makes it possible for the residents to be part of the process from the very beginning" (Interviewee 1, 2019).

This idea aligns with that of Zenker and Martin (2011) according to which the residents should receive support to implement their projects. 
JPMD

14,3

288
Case example 2: Participatory budgeting

Background. The second case comes from Helsinki, the capital of Finland, demonstrating how residents are engaged in the city's budgeting and thereby its development and branding. The process is called OmaStadi (my city) and involves participatory budgeting, where the city administrators have set aside a budget of EUR 4.4m budget to spend on developing Helsinki at the city level and/or in major districts. The residents of the city are asked for ideas on how the money should be spent. The city is divided into seven major districts and funds are allocated to each according to the number of residents. Each district has its own borough liaison contact who is responsible for promoting participation among special groups, enhancing regional collaboration and implementing participatory budgeting. The liaison people are used by the city and have to have a good knowledge of their own district (OmaStadi, 2018).

The participatory process was initiated by the mayor of Helsinki in 2016 when he appointed a committee to address residents' opportunities to participate in city policy and planning. The participatory model was prepared with some 200 residents through various discussion events and workshops; participation in the preparation was also possible via an electronic survey. Three principles delineated the model:

- Exploiting the expertise of individuals and communities.

- Enabling spontaneous actions.

- Creating equal opportunities to participate.

The OmaStadi model was created using service design tools and on principles of parity. Accordingly, the model aims to have residents participate in city planning to improve the interaction between them and the city. Moreover, the model has to meet the requirements of the EU directive on accessibility, that is, it has to be provided in a way that is equally accessible for all the residents. The service, therefore, must be both accessible on all internetcapable devices and to those citizens lacking an internet connection. Consequently, voting was made possible in libraries, residential centers and old people's homes. The designers paid attention to the communication: the service is offered in several languages and through several channels: online, print, social media, service points, outdoor advertising, events and meetings (Interviewee 2, 2019).

In the first round, the tools for participation were versatile, ranging from online options, that is, access to the OmaStadi portal (OmaStadi, 2018) and giving feedback online in faceto-face meetings in the form of the mayor's residents' evenings. Senior citizens were given digital skills training to encourage them to participate and have their say.

While an ideal, not everybody was expected to be equally active or committed. Before the project launch, the OmaStadi project leaders interviewed residents from various suburbs, asking them about their previous and future willingness to participate and any obstacles they perceived as limiting their participation (Figure 1). The profiling aimed to create an overall view of the participation and communication needs of the residents to be able to reach as many people as possible and to motivate them to participate in the actual project. A group that here labeled the snoozer group proved to be the largest and most challenging (OmaStadi, 2018).

Results of the first OmaStadi project. The above participation profiles were used in the OmaStadi marketing campaign to support idea generation and to motivate people to vote. In all, 4,665 residents participated in the actual OmaStadi idea-generation process in November and December 2018, producing 1,273 suggestions, of which the evaluation committee considered 839 might be possible to implement. Of those, 359 were subjected to more 


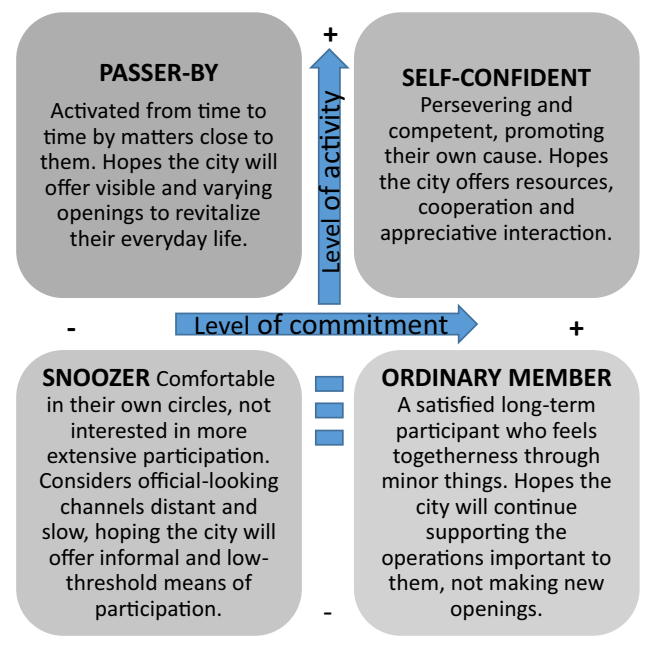

Voice of dwellers

289

concrete planning and costing by the city planners in spring 2019. In the final step, the residents were able to vote for the ideas in October 2019 and 45,821 citizens took that opportunity. After the mayor announced the decision on the vote in November 2019, those initiatives receiving the highest number of votes were implemented. The residents were also invited to participate in this phase. The challenge was the delay of more than 18 months between the idea generation and the final realization; some residents may have lost interest during the implementation phase (Interviewee 2, 2019). However, the first OmaStadi project generated observations that can be useful for future rounds (Table 2). Then, there will be future rounds, even with bigger budgets: the city decided to launch a second OmaStadi project with a doubled budget (EUR 8.8m) in fall 2020 (Oksanen, 2020). The key determinants of the first process are listed in the right-hand column.

Of the above, particularly residents' commitment and respect feature in the previous literature; Zenker and Seigis (2012, p. 24) underline the mediating role of respect in citizen participation: participation as an opportunity for residents to express their opinion should help them feel respected, create a feeling of being treated fairly and eventually lead to deeper commitment (see also, e.g. Insch and Stuart, 2015; Braun et al., 2013; Insch and Florek, 2010).

The ways in which Turku and Helsinki listen to their residents echo the features of Macnamara's (2016) organizational listening: both have created an open culture (anybody can take the initiative), interactive systems and forums (off-line and online possibilities), as

\begin{tabular}{|c|c|}
\hline Observation & Key determinant \\
\hline Everybody wants Helsinki to be a better city & Residents' commitment \\
\hline $\begin{array}{l}\text { Residents are ready to share their expertise and knowledge for the common } \\
\text { good }\end{array}$ & $\begin{array}{l}\text { Common good for the benefit } \\
\text { of the city }\end{array}$ \\
\hline The measure of successful participation is not unanimity but a fair process & Fair process \\
\hline $\begin{array}{l}\text { Participation must strengthen understanding and respect between different } \\
\text { resident groups }\end{array}$ & Understanding and respect \\
\hline $\begin{array}{l}\text { here is a lot of expertise, notable success and many motivated employees in } \\
\text { e participatory process }\end{array}$ & \\
\hline
\end{tabular}

channels distant and

eshold means of

erations important to

not maki
Figure 1.

Primary OmaStadi participation profiles

(OmaStadi, 2018)

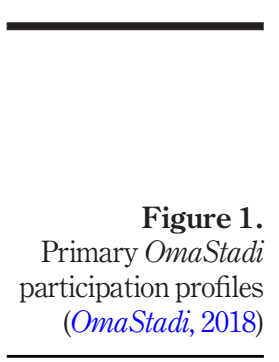


JPMD

14,3

290

well as technologies (digital platforms) for listening. Moreover, in both cities, resources including staff (the borough liaisons in Helsinki and the area coordinator in Turku) are assigned to operate the listening and to offer consultation and assistance when needed. As noted above, participation can take different forms and the extent of the citizens' power can vary. Placed on Arnstein's (1969) ladder of participation, the Mayor's Visits concept is positioned among the middle rungs: it is a question of informing [both from the residents' and city's side], consultation and placation, as it is not guaranteed that the residents' views and opinions would be taken into account. In Helsinki, on the other hand, the participation reaches the upper three rungs - partnership, delegated power and citizen control - as the residents are empowered with a greater degree of power and opportunities to influence and in the future, even to take part in the execution of the projects. According to Interviewee 2 (2009), deep participation offers residents opportunities to take part in the implementation as well. However, according to Interviewee 1 (2019), the greatest way to influence is still to vote in the municipality elections.

Interestingly, after the positive results from Helsinki, the city of Turku also decided to launch a participatory budget model in spring 2020. The name for the model, the Resident Budget was crowdsourced from dozens of suggestions (Turku, 2020). The model allows Turku residents to propose, develop and ultimately vote on how to spend $1 \mathrm{~m}$ euros from the city budget. Proposals may include improvements to the living environment, joint activities, innovative events and new types of services, with a particular emphasis on residents' wellbeing (Interviewee 3, 2020). In a manner similar to the OmaStadi model of Helsinki, Turku's Resident Budget focuses on parity principles, that is, ensuring everybody above 13 years of age has the opportunity to participate and ensuring that submitting suggestions and voting can be conducted via online and off-line channels including through a Resident Budget website and in libraries. Moreover, assistance has been planned to be provided to care home residents on site. Unfortunately, the Covid-19 pandemic undermined the plans and the live events had to be canceled, which may have affected residents' awareness of the project, as well as voting activity (Peltomaa, 2020); a total of 340 proposals was made and just 2,389 residents participated in the ballot (Turun Sanomat, 2020). Together with the Resident Budget, Turku will have two different models for listening to the residents.

\section{Meeting the challenges of listening in place branding}

This section responds to the second research question by first briefly addressing the benefits and thereafter, reviewing the challenges of listening to residents based on the previous literature. Subsequently, the article uses the Mayor's Visits and OmaStadi participatory budgeting to illustrate what cities could do to meet the challenges in place development and branding. The two cases exemplify how listening to the existing residents - those who live the brand - can be an asset in developing the place and its brand. Both examples have features of Braun et al.'s (2013) three-fold roles of residents in place branding. Helsinki, by giving the residents a chance to participate in the allocation of the city budget and thereby in the placeprotective behavior and social well-being of their own neighborhood, has tried to increase place attachment (Phillips et al., 2010; Fleury-Bahi et al., 2008). A stronger attachment to and identification with the place can transform the residents into authentic ambassadors (Zenker and Erfgen, 2014; Klijn et al., 2012). In Turku, on the other hand, the possibility to meet the mayor and other city representatives face-to-face lowers the barrier between the populace and the authorities, engages passive resident segments, enhances collaboration between city officials and prevents silos. This kind of listening and dialogue between the city officials and the residents is likely to increase brand commitment and turn people into influencers (Braun et al., 2013). 
Despite its benefits, resident participation cannot be taken for granted. It can have unintended consequences that can lead to failures to meet its objectives (Turnhout et al., 2010). Prior literature offers some examples: First, according to O'Neill (2001), it is impossible to involve everybody, and hence, participation can never be complete; some residents will always be left without a voice. This view is echoed by Riezebos (2007), who asserts that applying branding and democracy are incompatible. Second - and relatedly social closure creates a sense of discrimination and can be the cause of social tension and violence toward and among minority groups such as immigrants (Eshuis and Edwards, 2013). In a public context, no groups should be ignored (Eshuis et al., 2013). According to García (2006; see also Lichrou et al., 2017), everyone inside the community, regardless of origin or background, should be entitled to take part equally in the spheres of justice. Third, the aim of achieving consensus can result in groupthink: the active residents' opinions and claims may outweigh alternate courses of action as the capacity to both speak out and to be heard are unevenly distributed (Mosse, 2001; O’Neill, 2001).

Fourth, political bodies exert a high degree of control in municipalities (Eshuis et al., 2013) and participation can be restricted right from the emergence of the issues at stake if goals are already predefined (Turnhout et al., 2010). People can feel there is no alignment between what they perceive should be done and what the city is doing (Insch and Stuart, 2015). Support from the place authorities is needed to obtain good results, but they may find themselves operating beyond their sphere of competence (Ind and Bjerke, 2007). The authorities can also feel pressure stemming from demands they cannot meet: "People easily think that the city is responsible for 'everything" (Interviewee 1, 2019). Fifth, the processes may take longer than expected, which can create communication challenges. Internal communication throughout the process is essential to recognize the opportunities for participation (Insch and Stuart, 2015) and to be aware of the residents' commitment to and identification with their city. Place communication that focuses mainly on external audiences can be detrimental to cities (Zenker and Petersen, 2014). Lack of knowledge can hinder residents from being involved and sharing positive word-of-mouth (Insch and Stuart, 2015).

How to override these challenges? How to make sure that participation is not exclusive, selective or restricted to just those who are active? How have the cities of Turku and Helsinki listened to their residents and taken the challenges into account in their participation processes?

Challenge 1: Undertaking genuine listening, involving as many residents as possible is an organizational and communication task.

According to Turnhout et al. (2010; see also Ind and Bjerke, 2007), passive residents can become involved in the participatory processes are organized openly, made accessible to everybody and the place authorities are genuinely interested and willing to listen to the residents. This calls for open information conveyed through channels and media that are accessible to all. In Turku, the flow of communication is the responsibility of the area coordinator, youth workers and residents' associations:

"In a way, the communication is two-stage: the area coordinator - together with the youth workers and residents' associations - first monitors the situation in the area and creates an agenda. Thereafter, we have the visit where the people have the opportunity to discuss the issues raised or bring new topics to the table." (Interviewee 1, 2019)

In Helsinki, the borough liaison officers have a major role. Furthermore, both cities are aware of the challenge of passive residents being excluded from decision-making; the larger the groups of people concerned, the less incentive to become involved the residents feel they 
JPMD

14,3

have (Olsson and Berglund, 2009). This challenge is tackled by dividing the cities into smaller regions; Turku is divided into eight regions and each region meets the mayor to discuss its own initiatives. In Helsinki, there are seven major districts, each with a borough liaison officer who is then responsible for ensuring everyone has an equal opportunity to participate.

Challenge 2: Social closure, based on people's diverse origins and backgrounds, creates a sense of discrimination and can cause social tension and a lack of unity of purpose.

The administrations of both Turku and Helsinki emphasize an equal right to participation. In Helsinki, the OmaStadi model is based on parity principles and inclusive participation. Accordingly, the service has to meet the requirements of the EU directive on accessibility, that is, it has to be provided in a way that is equally accessible for all the residents. A grassroots example of this is the collaboration with Nicehearts, an association for immigrant women founded in 2001 to help them take their place as equal members of society (Interviewee 2, 2019; Nicehearts, 2019). In Turku, participation is encouraged by participatory city-development projects that pay particular attention to the needs of immigrants, people with disabilities, the elderly, the youth and children. Further, in Turku, immigrant women have been active in forming networks and starting initiatives for the Mayor's Visits program.

With regard to the third challenge and based on the theory (Mosse, 2001; O'Neill, 2001), we can specify another challenge:

Challenge 3: The aim to achieve consensus can result in groupthink as the active residents' opinions and claims may outweigh alternate courses of action.

Here again, the division of the cities into smaller regions can activate residents as they are closer to the plans and decisions made, to the extent that they are even part of their everyday life. In Helsinki, the challenge of groupthink is tackled by letting people vote individually on over 300 initiatives. The voting ended at the end of October 2019 and 45,821 votes were recorded on regional initiatives and 21,044 votes on the development of the whole city. The most active region was central Helsinki, which recorded 10,429 votes. In Turku, besides informing the residents about the upcoming Mayor's Visits in different regions, the residents' associations play an important role in encouraging people to attend the events.

The fourth challenge is connected with the prioritization of the issues at stake:

Challenge 4: Participation can be restricted from the start of the issues at stake and goals are already predefined.

This challenge can be countered by applying the bottom-up principle. In Turku, the initiative and topics for the visits stem from the residents and the area coordinator will then help the residents organize the event. By doing this, the city can approach segments of the population that would not necessarily be heard in decision-making. This is in line with the claim made by Eshuis and Klijn (2012) that people feel more committed to a brand if they have been involved in its construction and content. With regard to Helsinki, Interviewee 2 (2019) emphasized the fact that the first OmaStadi round exemplified joint development involving all parties. One of the features that will be developed for future rounds is the implementation of the plans: currently, the city will implement the plans, whereas, in the future, the residents will be tasked with realization too. This represents a demand-oriented city as a platform process that enables and facilitates citizen-led innovation through an open ecosystem (Interviewee 2, 2019; Van Ransbeeck, 2019). It also facilitates full utilization of digital platforms as urban dwellers now live in hyper-connected virtual spaces, pulsing with real-time information, intelligent devices and remote-access databases. 
Challenge 5: Lack of knowledge and information can hinder residents' involvement and participation.

Referring to Insch and Stuart (2015), effective communication with the residents and giving them a chance to participate in the city-governance processes should be today's priority in city branding. However, if they are to get involved and participate, the residents should be aware of their options and be made aware of the timetable and progress of the project, as highlighted by Interviewee 2 (2019): "We have to be able to actively communicate to the residents how the ideas and plans are proceeding." Building awareness and brand knowledge is the primary communication objective, among all target groups, regardless of the media used (Rosenbaum-Elliott et al., 2015). As residents are not a homogeneous target, the media used must cater to the various subgroups and communicate optimally with them (Zenker and Braun, 2017). However, one-way communication is not enough: "The city should appreciate the information gained from the residents and take it into consideration in the governance" Interviewee 2 (2019). Feedback and two-way communication are also emphasized by Insch and Stuart (2015). According to Interviewee 1 (2019), the messages can still transfer via WOM and eWOM even if people did not participate in the actual Mayor's Visits program: "Even if [a person] does not take part in the event, (s)he will most likely participate in the discussion in the area."

As stated earlier in this paper, judicial regulations and limited economic resources restrict cities from doing anything they wish and also from meeting all their residents' demands. In addition, residents do not always know how far a city's responsibilities go: "The residents usually think that the city is responsible for everything and every little detail [...]. But in fact, every citizen has an important role." (Interviewee 1, 2019) Moreover, according to Interviewee 2 (2019): "You are the city, meaning that the residents make the city.” However, both Interviewee 2 (2019) and Interviewee 1 (2019) state that the city authorities themselves are ultimately responsible for the external image of the city brand and in creating that brand they should listen to the city dwellers.

\section{Conclusions and recommendations}

Creating unity of purpose calls for listening, open communication, equal rights and opportunities for everyone to participate. This is true in all governance, not least in city governance. Having a voice is a human right and city authorities should facilitate that right by listening to their residents. Based on the literature review and the findings of this study, we can draw conclusions and make recommendations that have both theoretical values and offer a managerial contribution. First, creating awareness of the opportunities for participation and giving the residents a chance to be involved in the city decision-making positively influences their commitment to the city and also has an indirect effect on the city brand. Creating such awareness calls for effective primary and secondary communication by the city officials throughout the processes (see Kavaratzis, 2004); people have to be aware of the opportunities for participation. The importance of communication has been underlined by Kapferer $(2014,163$; see also Braun et al., 2014; Zenker and Braun, 2017): "Brands can only exist if they communicate." This wisdom applies to any brand, including place brands and communication within the city. Accordingly, referring to Grabow and Hollbach-Grömig (1998 [4]; cited in Kavaratzis, 2004), the competence and success of a city depend on its functional communication in all phases of place development (from the preparation phase through planning to finalization). 
JPMD

14,3

294

Second, participation should not be restricted based on someone's origin, age, gender or any other feature (García, 2006; Lichrou et al., 2017). All citizens should enjoy equal rights and an equal opportunity to have their say. The two cases discussed in this paper are examples of giving people such a chance. Both cities have paid particular attention to encouraging groups that would not necessarily be heard in the course of decision-making children, teenagers, immigrants, the elderly and the disabled - to participate and have their say.

Third, residents should not be treated as one homogeneous group and as an objectified target. Instead, they should be seen as active and able citizens. Reaching them can be facilitated by segmenting them into subgroups based on their area of residence, participation activity, ability to participate, place of origin and mother tongue (Zenker and Braun, 2017). The bigger the city, the more important this micro-segmentation is. Helsinki, the capital of Finland, is divided into seven major districts and in each of them, the budget funds are allocated according to the number of residents. Each district has its borough liaison officer who is responsible for promoting participation among special groups, enhancing regional collaboration and executing the participatory budgeting. Turku, the sixth-largest city in the country with a population of 185000 people, is divided into eight regions based on the number of inhabitants and the mayor meets the residents of these regions between two and four times a year. Fourth, the participatory practice should stem from the grassroots level and move upward as the immediate neighborhood is where people live their everyday life (Braun et al., 2013; Morgan et al., 2003; Kavaratzis, 2009; Baker, 2012). Accordingly, listening and reacting to even small issues that pop up in the processes should not be neglected. In the case of the Mayor's Visits, the initiatives for the gatherings and the topics are elicited from the residents. In the case of participatory budgeting, all residents are invited to submit ideas for developing Helsinki at the city level and/or in major districts by the due date. Thereafter, people can vote for the ideas and the most popular will be implemented. In Helsinki, the process is a two-phase one that starts with idea generation and then introduces voting, which makes it possible for people to participate in either stage or both.

\section{Limitations and suggestions for future research}

Integrating insights from expert interviews and documentary material, this paper has introduced and analyzed ways of listening to residents in place branding processes in two Nordic cities. Alas, it is limited by its scale and methodology, that is, the findings are reflective of only two cities in Finland and the methods used were qualitative. Follow-up research could apply quantitative methods and collect data to reveal generalizable findings. A logical extension would be to investigate if and how other cities, preferably in other countries, listen to their residents and let their place brand grow from the bottom. This idea is in line with Braun et al.'s (2013) call for more research on the integration of residents in place branding and investigating the roles in practice. The role of residents and the importance of listening are crucial features in the emerging concept of inclusive place branding (Kavaratzis et al., 2017); its future conceptual development could benefit from the case examples offered here.

Accordingly, investigating how residents' ability to participate in the city governance influences the city's brand and the image is an area for an extensive beforeand-after study. Based on the findings of this study, we can only assume that having a chance to participate increases commitment and attachment to a place, thereby establishing loyalty among the residents and in the long run, improving the city's brand. How the causal relationship develops requires the use of quantitative methods 
(see, e.g. Olsson and Berglund, 2009) and analysis of the cause-effect relationship and its intensity. Moreover, to understand the worth of listening from the perspective of those who are participating, we should conduct a survey among residents that seeks to elicit: Who participates? What do they expect from the collaboration? What is the value of participation for them? Why do they participate? If they do not, why not? The participation profiles described above - passer-by, self-confident, snoozer and ordinary member - could be used as a starting point.

As the above suggestions for further research show, listening is an important theme in place branding from many perspectives. City authorities must provide opportunities for residents to actively contribute to decision-making and thereby, help the city brand be responsive to citizens and reflect the existing identity of the community (Braun et al., 2013; Eshuis and Edwards, 2013). In this respect, discussion on the topic can enhance both theory and practice.

\section{Notes}

1. In this article, the terms citizens and residents are used interchangeably. The term "dwellers" used in the title encompasses both descriptions.

2. Webster's Dictionary (2020) defines participation as the "act of participating", that is, having a share or part in something, whereas involvement means "to engage as a participant" and "to oblige to take part."

3. Turku Future Forums are 3-4 h open and interactive sessions, focusing on city development. The forum was initially designed to engage city residents and other stakeholder groups in strategic envisioning processes, which target strategic, comprehensive and long-term city development in terms of competitiveness, attractiveness, sustainability and well-being (www.balticurbanlab.eu/ goodpractices/turku-future-forum-co-creating-future-city).

4. Original source: Grabow, B. and Hollbach-Grömig, B. (1998) Stadtmarketing - eine kritische Zwischenbilanz, Deutches Institut für Urbanistik, Difu, Berlin.

\section{References}

Ahmed, J.U. (2010), “Documentary research method: new dimensions”, Indus Journal of Management and Social Sciences, Vol. 4 No. 1, pp. 1-14.

Alexander, E. (2008), "Public participation in planning - a multidimensional model: the case of Israel", Planning Theory and Practice, Vol. 9 No. 1, pp. 57-80.

Appleton, J.V. and Cowley, S. (1997), "Analysing clinical practice guidelines. A method of documentary analysis", Journal of Advanced Nursing, Vol. 25 No. 5, pp. 1008-1017.

Arnstein, S.R. (1969), "A ladder of citizen participation”, Journal of the American Institute of Planners, Vol. 35 No. 4, pp. 216-224.

Baker, B. (2012), Destination Branding for Small Cities. The Essentials of Successful Place Branding, 2nd ed., Creative Leap Books, Portland, OR.

Blomgren Bingham, L., Nabatchi, T. and O'Leary, R. (2005), "The new governance: practices and processesfor stakeholder and citizen participation in the work of government", Public Administration Review, Vol. 65 No. 5, pp. 547-558.

Braun, E., Eshuis, J. and Klijn, E.H. (2014), “The effectiveness of place brand communication”, Cities, Vol. 41 No. 1, pp. 64-70.

Braun, E., Kavaratzis, M. and Zenker, S. (2013), "My city - my brand: the different roles of residents in place branding", Journal of Place Management and Development, Vol. 6 No. 1, pp. 18-28. 
$\mathrm{JPMD}$ 14,3

Cassinger, C. and Eksell, J. (2017), "The magic of place branding: regional brand identity in transition", Journal of Place Management and Development, Vol. 10 No. 3, pp. 202-212.

Cho, J. and Trent, A. (2003), "Validity in qualitative research revisited", Qualitative Research, Vol. 6 No. 3, pp. 319-340.

Colicev, A., Malshe, A., Pauwels, K. and O'Connor, P. (2018), "Improving consumer mindset metrics and shareholder value through social media: the different roles of owned and earned media", Journal of Marketing, Vol. 82 No. 1, pp. 37-56.

Colomb, C. and Kalandides, A. (2010), "The 'be berlin' campaign: old wine in new bottles or innovative form of participatory place branding?", in Ashworth, G.J. and Kavaratzis, M. (Eds) Towards Effective Place Brand Management: branding European Cities and Regions, Edward Elgar, Cheltenham, pp. 173-190.

Compte-Pujol, M., de San Eugenio-Vela, J. and Frigola-Reig, J. (2019), "Key elements in defining barcelona's place values: the contribution of residents' perceptions from an internal place branding perspective", Place Branding and Public Diplomacy, Vol. 14 No. 4, pp. 245-259.

Daymon, C. and Holloway, I. (2011), Qualitative Research Methods in Public Relations and Marketing Communications, 2nd ed., Routledge, London.

Eisenhardt, K.M. (1989), "Building theories from case study research", Academy of Management Review, Vol. 14 No. 4, pp. 532-550.

ePressi (2018), "Kaupunginjohtaja arve kylässä varissuolla, jyrkkälässä ja runosmäessä [mayor arve visits varissuo, jyrkkälä and runosmäki] the article available in the internet at", www.epressi. com/tiedotteet/kaupungit-ja-kunnat/kaupunginjohtaja-arve-kylassa-varissuolla-jyrkkalassaja-runosmaessa.html (accessed 10 August 2020).

Eshuis, J. and Edwards, A. (2013), "Branding the city: the democratic legitimacy of a new mode of governance", Urban Studies, Vol. 50 No. 5, pp. 1066-1082.

Eshuis, J. and Klijn, E.H. (2012), Branding in Governance and Public Management, Routledge, London.

Eshuis, J., Braun, E. and Klijn, E.H. (2013), "Place marketing as governance strategy: an assessment of obstacles in place marketing and their effects on attracting target groups", Public Administration Review, Vol. 73 No. 3, pp. 507-516.

Eshuis, J., Klijn, E.H. and Braun, E. (2014), "Place marketing and citizen participation: branding as strategy to address the emotional dimension of policy making?", International Review of Administrative Sciences, Vol. 80 No. 1, pp. 151-171.

Etikan, I., Musa, S.A. and Alkassim, R.S. (2016), "Comparison of convenience sampling and purposive sampling", American Journal of Theoretical and Applied Statistics, Vol. 5 No. 1, pp. 1-4.

Fleury-Bahi, G., Félonneau, M.L. and Marchand, D. (2008), "Processes of place identification and residential satisfaction", Environment and Behavior, Vol. 40 No. 5, pp. 669-682.

Flyvbjerg, B. (2006), "Five misunderstandings about case-study research”, Qualitative Inquiry, Vol. 12 No. 2, pp. 219-245.

Freire, J.R. (2009), "Local people: a critical dimension for place brands", Journal of Brand Management, Vol. 16 No. 7, pp. 420-438.

Frug, G.E. (1984), "The city as a legal concept”, in L. Rodwin and R.M. Hollister (Eds) Cities of the Mind. Images and Themes of the City in the Social Sciences, Springer, MA, pp. 233-290.

García, M. (2006), “Citizenship practices and urban governance in Europen cities”, Urban Studies, Vol. 43 No. 4, pp. 745-765.

Grabow, B. and Hollbach-Grömig, B. (1998), "Stadtmarketing - eine kritische Zwischenbilanz, Deutches Institut für Urbanistik", Difu, Berlin. 
Hakala, U., Lemmetyinen, A. and Nieminen, L. (2020), "Rebranding a 'rather strange, defnitely unique' city via co-creation with its residents", Place Branding and Public Diplomacy, Vol. 16 No. 4, pp. 316-325.

Hatch, M.J. and Schultz, M. (2009), "From corporate to enterprise branding”, Organizational Dynamics, Vol. 38 No. 2, pp. 117-130.

Hudson, S., Cárdenas, D. and Meng, F. (2017), "Building a place brand from the bottom up: a case study from the United States", Journal of Vacation Marketing, Vol. 23 No. 4, pp. 365-377.

Ind, N. and Bjerke, R. (2007), Branding Governance: A Participatory Approach to the Brand Building Process, Wiley, London.

Insch, A. and Florek, M. (2010), "Place satisfaction of city residents: findings and implications for city branding", in Ashworth, G.J. and Kavaratzis, M. (Eds.) Towards Effective Place Brand Management: branding European Cities and Regions, Edward Elgar, Cheltenham, pp. 191-204.

Insch, A. and Stuart, M. (2015), "Understanding resident city brand disengagement", Journal of Place Management and Development, Vol. 8 No. 3, pp. 172-186.

Kalandides, A. (2011), "City marketing for Bogotá: a case study in integrated place branding”, Journal of Place Management and Development, Vol. 4 No. 3, pp. 282-291.

Kapferer, J.N. (2014), The New Strategic Brand Management: Advanced Insights and Strategic Thinking, Kogan Page, London.

Kavaratzis, M. (2004), "From city marketing to city branding: towards a theoretical framework for developing city brands", Place Branding and Branding, Vol. 1 No. 1, pp. 58-73.

Kavaratzis, M. (2009), “Cities and their brands: lessons from corporate branding”, Place Branding and Public Diplomacy, Vol. 5 No. 1, pp. 26-37.

Kavaratzis, M. and Ashworth, G.J. (2005), "City branding: an effective assertion of identity or a transitory marketing trick?", Tijdschrift Voor Economische en Sociale Geografie, Vol. 96 No. 5, pp. 506-514.

Kavaratzis, M., Giovanardi, M. and Lichrou, M. (2017), Inclusive Place Branding. Critical Perspectives on Theory and Practice, London: Routledge.

Kehe (2018), "Maarian nuorisotalo aka kehe 2018 [youth club kehe 2018]", available in the internet at www.youtube.com/watch?v=QQrchKM8JiQ (accessed 10 August 2020).

Keller, K.L. (1993), "Conceptualizing, measuring and managing customer-based brand equity”, Journal of Marketing, Vol. 57 No. 1, pp. 1-22.

Klijn, E.-H., Eshuis, J. and Braun, E. (2012), "The influence of stakeholder involvement on the effectiveness of place branding", Public Management Review, Vol. 14 No. 4, pp. 499-519.

Koelsch, L.E. (2013), "Reconceptualizing the member check interview", International Journal of Qualitative Methods, Vol. 12 No. 1, pp. 168-179.

Kuntaliitto (2020), "Kuntalaisten osallistuminen [participation of citizens], association of finnish municipalities", available in the internet: www.kuntaliitto.fi/osallistuminen-ja-vuorovaikutus/ demokratia-ja-osallisuus/kuntalaisten-osallistuminen, (accessed 17 November 2020).

Lacey, K. (2013), Listening Publics: The Politics and Experience of Listening in the Media Age, Wiley Blackwell/Polity, Malden, MA.

Leininger, M.M. (1994), "Evaluation criteria and critique of qualitative studies", In: Morse Janice M. (Ed.) Critical Issues in Qualitative Research Methods, Newbury Park, CA: Sage. pp. 95-115.

Lichrou, M., Kavaratzis, M. and Giovanardi, M. (2017), "Introduction”, In: Kavaratzis, M., Giovanardi, M. and Lichrou, M. (Eds), Inclusive Place Branding. Critical Perspectives on Theory and Practice, London: Routledge. pp. 24-33.

Lincoln, Y.S. and Guba, E.G. (1985), Naturalistic Inquiry, Beverly Hills, CA: Sage. 
$\mathrm{JPMD}$ 14,3

Lucarelli, A. and Giovanardi, M. (2016), "The political nature of brand governance: a discourse analysis approach to a regional brand building process", Journal of Public Affairs, Vol. 16 No. 1, pp. 16-27.

Macnamara, J. (2016), “Organizational listening: addressing a major gap in public relations theory and practice", Journal of Public Relations Research, Vol. 28 Nos 3/4, pp. 146-169.

Merrilees, B., Miller, D. and Herington, C. (2009), "Antecedents of residents' city brand attitudes", Journal of Business Research, Vol. 62 No. 3, pp. 362-367.

Morgan, N.J., Pritchard, A. and Piggott, R. (2003), "Destination branding and the role of stakeholders: the case of New Zealand", Journal of Vacation Marketing, Vol. 9 No. 3, pp. 285-299.

Mosse, D. (2001), "People's knowledge', participation and patronage: operations and representations in rural development", in Cooke B. and Kothari U. (Eds) Participation: The New Tyranny?, Zed Books, London, pp. 16-35.

Myers, M.D. (2020), Qualitative Research in Business and Management, 3rd ed, Sage, Los Angeles.

Nicehearts (2019), "Muutos on meissä kaikissa [in english: Change stems from all of us]", available in the internet: www.nicehearts.com/ (accessed 12 November 2019).

Oksanen, K. (2020), "Helsinkiläiset haluavat säilyttää arvotalonsa" [residents of Helsinki want to save their valuable houses]", The Helsingin Sanomat, p. A5, August 23, 2020.

Olsson, K. and Berglund, E. (2009), "City marketing: the role of the citizens", in Nyseth, T. and Viken, A. (Eds), Place Reinvention: Northern Perspectives, Ashgate, Surrey, London, pp. 127-144.

OmaStadi (2018), "Participatory budgeting makes your ideas and voice heard", available in the internet at https://OmaStadi.hel.fi/ (accessed 5 October 2019).

O'Neill, J. (2001), "Representing people, representing nature, representing the world", Environment and Planning C: Government and Policy, Vol. 19 No. 4, pp. 483-500.

Peltomaa, T. (2020), "Asukasbudjetti avaa turkulaisille mahdollisuuden vaikuttaa [the resident budget gives the residents of Turku a possibility to have an impact]", Turun Sanomat, September 26, 2020.

Phillips, D.R., Cheng, K.H.C., Yeh, A.G.O. and Sui, O.L. (2010), "Person-environment (P-E) fit models and psychological well-being among older persons in Hong Kong”, Environment and Behavior, Vol. 42 No. 2, pp. 221-242.

Ramsey, R.P. and Sohi, R.S. (1997), "Listening to your customers: the impact of perceived salesperson listening", Journal of the Academy of Marketing Science, Vol. 25 No. 2, pp. 127-137.

Riezebos, R. (2007), "City branding: sense or non-sense?”, (White Paper of the European Institute for Brand Management, European Institute for Brand Management, Rotterdam.

Rioux, L. and Werner, C. (2011), "Residential satisfaction among aging people living in place", Journal of Environmental Psychology, Vol. 31 No. 2, pp. 158-169.

Roper, S. and Davies, G. (2007), “The corporate brand: dealing with multiple stakeholders”, Journal of Marketing Management, Vol. 23 Nos 1/2, pp. 75-90.

Rosenbaum-Elliott, R., Percy, L. and Pervan, S. (2015), Strategic Brand Management, 3rd ed., Sage Publications, Oxford.

Sarpo, A. (2019), Helsingin Kaupungin Osallisuusmalli. Stadiluotsit ja Osallistuva Budjetointi [the Participatory Model of Helsinki. Borough Liaisons and Participatory Budgeting], Power point material provided by the City of Helsinki.

Sauri, P. (2017), "Luovuus ja luotettavuus ovat avain menestykseen" [creativity and reliability are the keys to success]", The Helsingin Sanomat, p. A5, August 1. 
Schultz, K. and McGinn, K.C. (2012), "No one cares about this community more than us: the role of listening, participation, and trust in a small urban district", Urban Education, Vol. 48 No. 6 , pp. 767-797.

Skinner, H. (2008), “The emergence and development of place marketing's confused identity”, Journal of Marketing Management, Vol. 24 Nos 9/10, pp. 915-928.

Smith, P.R. and Zook, Z. (2020), Marketing Communications. Integrating Online and Offline, Customer Engagement and Digital Technologies, 7 th ed., Kogan Page, London.

Stedman, R.C. (2002), "Towards a social psychology of place: predicting behavior from placebased cognitions, attitude, and identity", Environment and Behavior, Vol. 34 No. 5, pp. 561-581.

Steil, L.K., Barker, L.L. and Watson, K.W. (1983), Effective Listening - Key to Your Success, AddisonWesley, Boston.

Surowiecki, J. (2004), The Wisdom of Crowds: why the Many Are Smarter than the Few and How Collective Wisdom Shapes Business, Economies, Societies and Nations, Powell's Books.

Trueman, M., Cornelius, N. and Killingbeck-Widdup, A. (2007), "Urban corridors and the lost city: overcoming negative perceptions to reposition city brands", Journal of Brand Management, Vol. 15 No. 1, pp. 20-31.

Turku (2020), “Asukasbudjetti [Citizens' budget]", available at: https://asukasbudjetti.turku.fi/, (accessed 20 December 2020).

Turnhout, E., Van Bommel, S. and Aarts, N. (2010), "How participation creates citizens: participatory governance as performative practice", Ecology and Society, Vol. 15 No. 4 [online] URL: www. ecologyandsociety.org/vol15/iss4/art26/

Turun, S. (2019), "Kaupunginjohtaja kylässä -kierroksella vuorossa uittamo [mayor's visit to uittamo]", available in the internet at www.ts.fi/uutiset/paikalliset/4572678/, accessed 10 August 2020 .

Turun, S. (2020), “Nummi-Halisen suunnitelmille eniten ääniä [most votes for Nummi-Halinen area]”, October 3, 2020.

Van Ransbeeck, W. (2019), "City as a platform: How it changes governance, smart cities dive”, available online at: www.smartcitiesdive.com/ex/sustainablecitiescollective/city-platform-how-it-changesgovernance/1207636/, (accessed 15 November 2019).

Virgo, B. and de Chernatony, L. (2006), "Delphic brand visioning to align stakeholder buy-in to the city of Birmingham brand", Journal of Brand Management, Vol. 13 No. 6, pp. 379-392.

Webster's Dictionary (2020), "Online dictionary", available at: www.webster-dictionary.org/ accessed 15 November 2020.

Xiong, L. and King, C. (2015), "Motivational drivers that fuel employees to champion the hospitality brand", International Journal of Hospitality Management, Vol. 44, pp. 58-69.

Yang, S.U., Kang, M. and Cha, H. (2015), "A study on dialogic communication, trust, and distrust: testing a scale for measuring organization-public dialogic communication (OPDC)", Journal of Public Relations Research, Vol. 27 No. 2, pp. 175-192.

Yin, R.K. (2003), Case Study Research: Design and Methods, 3rd ed., Sage, Thousand Oaks, CA.

Zakarevičius, P. and Lionikaite, J. (2013), "An initial framework for understanding the concept of internal place branding”, Organizaciju Vadyba: Sisteminiai Tyrimai, Vol. 67, pp. 143-160.

Zenker, S. and Braun, E. (2010), "Branding a city: a conceptual approach for place branding and place brand management", Paper presented at The 39th EMAC Annual Conference 2010, Frederiksberg, Denmark.

Zenker, S. and Braun, E. (2017), "Questioning a 'one size fits all' city brand. Developing a branded house strategy for place brand management”, Journal of Place Management and Development, Vol. 10 No. 3, pp. 270-287. 
JPMD

14,3

300

Zenker, S. and Erfgen, C. (2014), "Let them do the work: a participatory place branding approach", Journal of Place Management and Development, Vol. 7 No. 3, pp. 225-234.

Zenker, S. and Martin, N. (2011), "Measuring success in place marketing and branding", Journal of Place Management and Development, Vol. 7 No. 1, pp. 32-41.

Zenker, S. and Petersen, S. (2014), "An integrative theoretical model for improving resident-city identification", Environment and Planning A: Economy and Space, Vol. 46 No. 3, pp. 715-729.

Zenker, S. and Seigis, A. (2012), "Respect and the city: the mediating role of respect in citizen participation", Journal of Place Management and Development, Vol. 5 No. 1, pp. 20-34.

Zenker, S., Eggers, F. and Farsky, M. (2013), "Putting a price tag on cities: insights into the competitive environment of places”, Cities, Vol. 30, pp. 133-139.

\section{Further reading}

Arnivaara, K. (2018), "Interview on 30th October, 2018. [interviewee 3]”.

Arve, M. (2019), "Interview on 11th October, 2019. [interviewee 1]".

Verkka, K. (2019), "Interview on $10^{\text {th }}$ October. [interviewee 2]".

Corresponding author

Ulla Hakala can be contacted at: ulla.hakala@utu.fi

For instructions on how to order reprints of this article, please visit our website: 